\title{
Corporation - Its Way of Performance and Its Presence in Some Transition Countries - with Specific Focus in South Eastern European Countries
}

\author{
Mirjeta Domniku \\ Lecturer of Business and Management Courses, Peja - Kosovo \\ mirjeta.domniku@unhz.eu
}

\section{Doi:10.5901/mjss.2015.v6n2s2p149}

\begin{abstract}
Corporation is the most and complex business and legal form, no matter for which country we take it in consideration. SME's, of course remains the most powerful economic weapon of each country, but, sometimes our mind do separate that some of especially medium business are registered and operates like corporations. Ownership, profit, management structure, etc., have a different look and structure if we relate and compare with business that are not corporations. But, in this paper we will be focused more on the presence of corporation in transitioning countries, their ranking level on economic based activities, and of course the focusing on using their natural resources in developing the corporation's activities. How important are corporation in economy of a country? Of course they employ a large number of employees and make a higher rate of production, but in other hand they are a great chance for individuals who have less entrepreneur skills and possess less characteristics, it a great chance to make an investment in financial assets of a company, by making their own business, respectively owners of corporate. We need do mention also that corporate performance has its impacts on the effective leadership, or as it is known the democracy corporate governance, in the present paper we will treat one part of this aspect.
\end{abstract}

Keywords: corporate, performance, structure, transition countries

\section{Introduction}

There are some factors which have been argued by researchers to be having a role in determining the disclosure level of corporation and environmental information related to firms' activities. The guidelines regarding the corporate and corporate governance and it performance definition are divided into two categories. On the one hand, it is envisaged the actual behavior of corporations regarding growth performance, efficiency, financial structure, relations with shareholders and stakeholders. On the other hand, there are concerns regarding the rules, respectively the regulations which are influencing the corporate activity. Corporate definition varies from country to another one, but what remains most important is that, owner's role in corporation relating with other business legal forms, rest passive in aspect of managerial or operative level. In our paper we will show some most usual concepts of a corporation, and of course we will remain by showing that how does corporation matches to fulfill at the higher degree their level of performance, with specific focus in some small leadership effects and indicators. Because this paper is a kind of a short paper based, we will introduce some of the most successful corporate that operates in some of transition countries, we specific focus in South Eastern European Countries (Kosovo, Albania, Serbia, Montenegro and Croatia). Except of the brand names of the companies, it will be explained the nature and the type of business activity they do, and of course relating their activities with the position of the country in aspect of potential of natural resources they possess. The level of profitability, growth, efficiency, productivity, and most is reached and increased sustainability and credibility of a corporation are manager's responsibility, but not even negligence of owners when it comes to make decisions in politic of dividend. This means that owners should think also to share and dedicate more money on investments and spending, because, if we want to have a well trained employees, with a great level of productivity, working effectively, and doing works with new IT and innovations, then owners should take more consideration on this. Hypothetically, this can be one of the main reasons that why corporate operates effectively, or better say they with better or constant performance. Corporate governance deals with the ways in which suppliers of finance to corporations assure themselves of getting a return on their investment" (Shleifer, 1997), in the U.S.A. being one of the best corporate governance systems from all over the world, with the U.K., Germany, and Japan, even if the last two have a different type of corporate governance system than the first ones. 


\section{Literature Review}

If we start to count the key characteristics of a Corporation, especially when we want to focus and to treat their impact in performance of Corporation, or at any medium sized Firm's at all (that usually have bigger numbers of employees), we need to make a separate literature review and of course followed at least at quantitative research. But, we will shortlist some of the key indicators that improve corporate efficiency and it performance, and some of main definitions that are used for corporation all around the Globe.

\subsection{Profitability}

One of the main objectives of each corporate, is to increase their level of profitability, and of course it can be done by reducing production costs, ex. lower cost of supply, reducing the working force cost (reorganization of duties in firm, etc.), or investing in new technologic equipment, etc, etc. For several reasons, profitability is found to be a reason for disclosing more information pertaining to the effects of corporation's activity on society and environment (Workthington A. C, 2014). In addition to this possible explanation, costs expected to be imposed- in case of achieving high levels of profitability- by some external groups such as

Trade unions (in form of calling for increasing workers' wages for example) might be an impetus for emphasizing the social and environmental role of the firm (employee's issues in the case of the example). Self-interest, such as keeping their positions, can be also taken into account by managers in their decisions with respect to social and environmental disclosure, since enhanced social image has increasingly become preferred by information users (Haniffa C. R., 2005).

\subsection{Efficiency}

Efficiency is related as mention above, as one of the crucial indicator's that can help profitability. Efficiency is explained in various ways from different authors, but can be understood in a very simple way: If a firm manages to produce at least $5 \%$ with lower expenditures in any kind of matter, then when can conclude that a firm is performing better. Efficiency is one of the most important indicators that affects the credibility and performance of an organization (SME or Corporate). Through efficiency, all the firms that operates in a specific location, market, or whatever, creates a specific advantage relating other competitors, because one of the main reasons is that, through efficiency, firms achieve to create better offers, better products, and of course operates with a better relative advantage.

\subsection{Corporation and Corporate governance used in different ways (languages, importance, etc.) in different countries}

A corporation is a company or group of people authorized to act as a single entity (legally a person) and recognized as such in law. Early incorporated entities were established by charter (i.e. by an ad hoc act granted by a monarch or passed by a parliament or legislature). Most jurisdictions now allow the creation of new corporations through registration. Registered corporations have legal personality and are owned by shareholders (Pettet, 2005) whose liability is limited to their investment. In American English the word corporation (CollinsDictionary.com, 2012) is most often used to describe large business corporations. In British English and in the Commonwealth countries, the term company is more widely used to describe the same sort of entity while the word corporation encompasses all incorporated entities. In American English, the word company can include entities such as partnerships that would not be referred to as companies in British English as they are not a separate legal entity.

There are two types of studies regarding the investigation of the relationship between corporate governance and firm performance, which used corporate governance ratings (Georgeta Vintilă, 2012). There are two of Corporate Governance types that are related with a firm's performance. Thus, the authors who have made the research in various countries (Australia (James-Overheu, 2009), Germany (Drobetz, 2004), Greece, etc.), developed an investment strategy which consisted in purchasing the shares in the lowest-G firms ("Democracy" firms, identified through strong shareholder rights) and selling the shares in the highest-G Firms ("Dictatorship" firms, identified through weak shareholder rights). Corporate that has higher in Democracy, or Dictatorship, are related directly with the ways and the level of effective leadership scale, for ex.

In 1945, Ohio State University made a research for determining the most effective leadership style (Lussier, 2008). According to a study based on the survey, managers had given answers based on two distinct dimensions (Likert, 1961):

a) Initiating structure. The principle is in which a manager plans, organizes, lead and supervise its employees in 
order to complete goals and objectives of a company.

b) Consideration. The principle is in which a manager achieve to develop a proper communication, confidence, friendly environment and respect.

Approximately at the same time when studies started in Ohio State University, the University of Michigan began studies on identifying the most appropriate leadership styles. Even at this University, were identified two main styles of leadership which they named with different terms (Domniku S. , 2012):

a) Work orientation. This resembles with Initiating structure, i.e., Managers are highly obliged in dedication to achieve higher performance in the enterprise.

b) Orientation towards workers. It also resembles with Consideration. These include concern and engagement of managers for needs and concerns of the employees.

But, let's focus a little bit on what or how corporation is defined or classified in Kosovo? Corporate in Kosovo are defined and may be considered in two main categories, which are (Mustafa, 2006). It is anticipated that the corporation may be Joint Stock and Limited Liability Companies.

a) Corporation as a Joint Stock Company is characterized as follows:

- Owners can transfer their shares without the consent of other shareholders of the company

- Joint stock company may conduct a public offering of its shareholders under the conditions provided by law

b) Limited Liability Company has the following characteristics:

- Shares are distributed only among its founders.

- The company may conduct a public offering of its shares or to offer these shares to an unlimited number of subjects

- In this society the number of shareholders cannot be greater than 50 .

- Shareholder of this company can sell its shares to other persons only with the consent of the company.

\section{Corporate - In Some of Transition Countries}

In follow, we will make an introduction of some of the most important indicators that will make this data research more compatible and should clarify the real situation about some subscription that have to deal with corporation (structure, most successful ones, etc.)

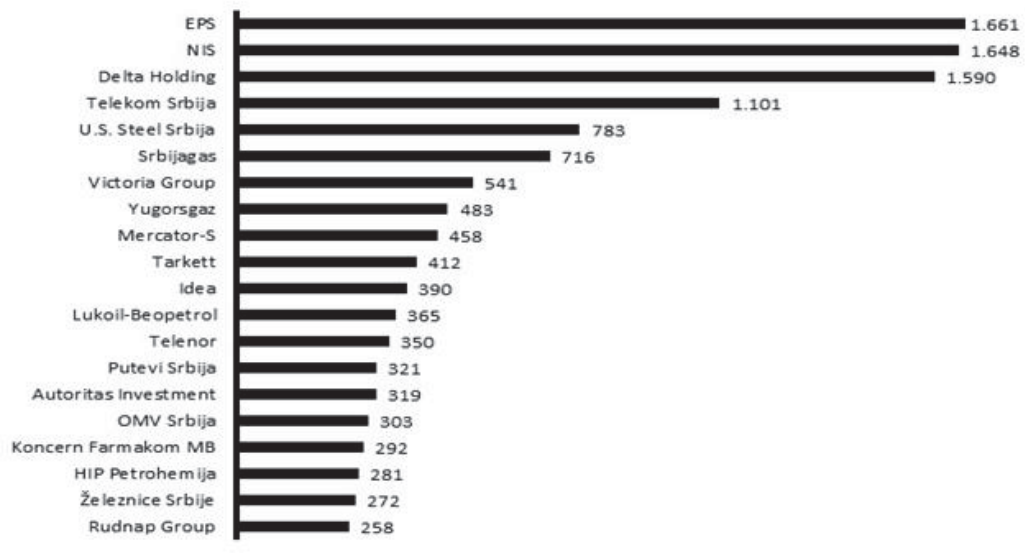

Table 1 - Some of most successful corporation in Serbia

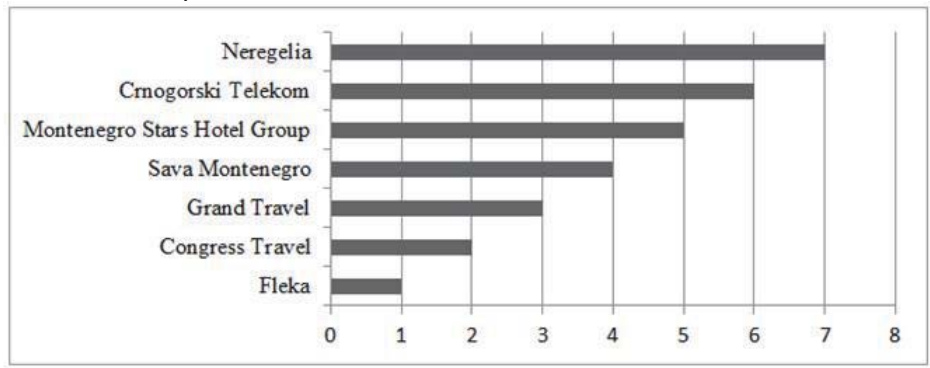


Table 2 - Some of most successful corporation's in Montenegro

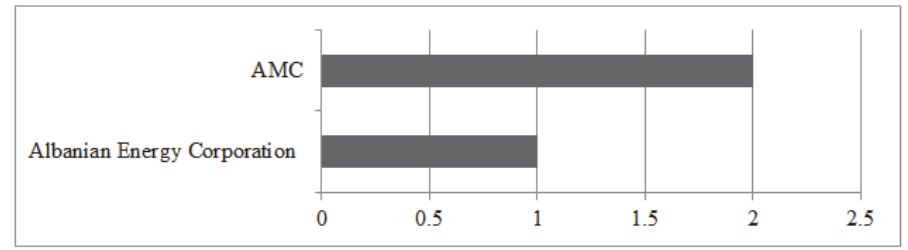

Source: http://www.cdm.me/ekonomija/sjutra-priznanja-za-najbolje-kompanije-u-crnoj-gori (last seen 19.11. 2014)

Table 3 - Two of most successful corporate in Albania

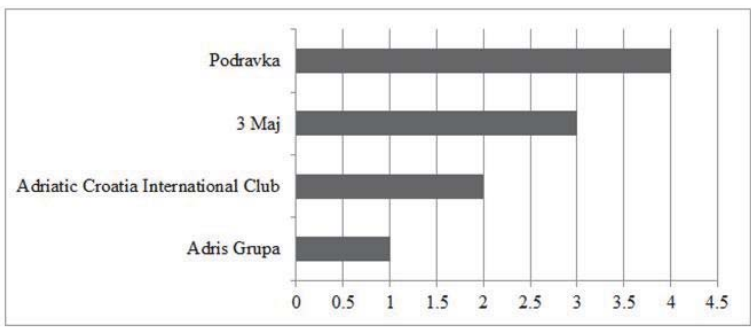

Source: http://www.noa.al/artikull/shpallen-kompanite-me-te-medha-ne-shqiperi-nder-shteteroret-kryeson-kesh-ngaprivatet-amc/15107.html (last seen 20.11. 2014)

Table 4 - Some of most successful corporate in Croatia

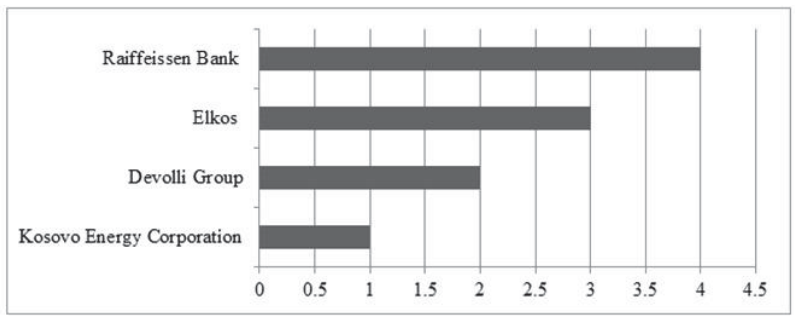

Source: http://en.wikipedia.org/wiki/List_of_companies_of_Croatia (last seen 21. 11. 2014)

\section{Discussions and Conclusions}

Our main goal of this study was the examination of the relationship between presence of corporation in some of south eastern countries, and it way of performance in a specific fields of economy.

In the tables showed above, we see some names of companies, but in fact, there is a huge variety of them, in aspect of their economic activity. For example, in one country, corporate are focused more in tourism, but in other hand some of them in trading and energy of telecommunications. We will make some comparing between countries we will get to some important conclusions below:

1. If we compare Albania and Kosovo, we can see that in Albania, there is still a need for the process of transformation of the property to be changed, since, still one of the country's leading corporations, to say the most powerful, are still owned by the public sector. While in Kosovo, in relation to Albania, we can see that in Albania corporations that dominate in this territory belongs to the scope in telecommunications, while in Kosovo, we can observe the corporations that have shown success in the field of trade and production. This does not exclude the possibility that in Albania are not developed these last two aforementioned such as in Kosovo, but mostly perhaps in non- corporate form.

2. If we compare Serbia with Kosovo, we can see that in Serbia there are corporations that their business activity support in the field of construction ,trade, product manufacturing machinery ( slopes, etc .) , 
Pharmaceutical products, but even the phone, etc . In other words, we see a much wider range of economic activities that rely on corporate structure or form.

3. Comparison of Montenegro with Kosovo, in terms of economic activities focused on corporations, even in this country can see a certain number of corporate and abundant, especially if we compare the population of Kosovo. But the main activities of businesses - Corporate, based mainly on tourism and hospitality, without ignoring the activity of cultivation and development of marine products, whether semi-product form or complete products.

4. Croatia, can be seen as presented (Table 4), the economic activities focused on corporate businesses, is significantly broader, if the resources that are offered, pore and if we are to thoroughly analyze each corporate to and explore the data source associated with economic activities in businesses form - corporation, are more extensive in other business area, including ; marine operations , manufacturing, aviation , pharmacy, multidimensional production (including various products or service). This is probably one of the reasons why Croatia may consider to be a serious competitors in the EU market, which is now also a member with full rights.

In general, when we observe that the difference of a country to another that businesses that have decided to operate as corporations, their activity mainly paved in absolute advantages to their own countries. The use of this advantage automatically creates the possibility that each corporation to have the relative advantage, since according to sources in his possession, can create such an advantage, whether produces better or lower cost.

Kosovo needs to use this advantage, that in my opinion are not used enough, especially advantage of the agricultural sector, through which this country can affect firstly the reduction of import, as we know that that in Kosovo import about $25 \%$ to $90 \%$ of total imports comprise consumer goods, but also in parallel supported employment growth in productivity, not only in numbers and statistics.

Like the other Balkan countries, their productive potential need to make the most rational, and that the form of business development corporation, is a good model that can serve not only business, but also individuals who are confused about where to place their investments, or on the other side are afraid to open any individual business, or either, do not possess the necessary tools to create a sustainable business and genuine. So investing in financial assets, in this case the shares of a corporation, it would be very appropriate and would affect the benefit in general.

The purpose of this conclusion, but also of this paper, not never misses the opportunity for businesses to develop and occur in two other legal forms (individual and partnership), but in some cases, is more than necessary, especially in the difficult situation that going through Kosovo, to organize seminars, conferences, etc., from institutions, NGOs, etc., and provided professional guidance as business experts and researchers in order Corporation, creation her and operation, to the benefit of all entities, including individuals, businesses, and also economy as a whole.

\section{References}

CollinsDictionary.com. (2012). Collins English Dictionary - Complete \& Unabridged.

Domniku, S. (2012). "Values of effective leadership in organisation" - Effects of Global Risk in Transition Countries , 120-118.

Drobetz, W. S. (2004). Corpoarte Governance and Expected Stock Returns - Evidence from Germany. European Financial Management , 267-293.

Drucker, P. (2006). Managing for Result. Harter Collins Publisher.

Georgeta Vintilă, Ş. C. (2012). An Empirical Examination of the Relationship between Corporate. Canadian Center of Science and Education , 7.

Haniffa C. R., C. T. (2005). The impact of culture and governance on corporate social reporting. Journal of Accounting and Public Policy , 391-430.

James-Overheu, C. (2009). Corporate Governance, Sustainability and the Assessment of Default. Asian Journal of Finance \& Accounting , 34-53.

Liden, R. C. (2000). Servant leadership: Development of a multidimensional measure and multi-level asssesment. The Leadership Quartely, 161-177.

Likert, R. (1961). New Patterns of Management. New York: McGraw-Hill.

Lussier, R. N. (2008). Human Relations in Organisation. New York: McGraw-Hill//rwin.

Mustafa, I. (2006). Udhëheqja - efiçenca dhe efektiviteti - Prishtinë: RIINVEST.

Pettet, B. G. (2005). Reading the above, makes it possible to forget that the shareholders are the owners of the company. USA: Pearson Education.

Shleifer, A., \& Vishny, R. (1997). A Survey of Corporate Governance. The Journal of Finance, 52(2), 737.

Workthington A. C, S. O. (2014). The Impact of Corporate Characteristics and Corporate Governance. International Journal of Business and Management, $9-12$ 
